\title{
Subject Position and Manifestations of Workplace Followership
}

\author{
Kedir Assefa Tessema \\ Wilkes University \\ Brianna Florovito
Wilkes University
}

This study examined three constructs of followership in the workplace context. Adopting a qualitative design and a conceptual framework based on the theories of subject positioning and sense-making, we explored organizational actors' underlying followership beliefs and meaning-making processes, and how they enact those beliefs and meanings in the context of follower-leader relationship. We analyzed interview data along the constructs followership positionality, sense-making and enactment. The findings indicate that followers situate their relationships in the evolving context of follower-leader relationship dynamics. They continuously engage in identity work and sense-making process to understand power and personal agency and adjust their engagements according to the constraint of authority hierarchy and the realms of workplace engagement possibilities, and opportunities for future career growth.

Keywords: subject positionality, workplace followership, followership enactment, follower sense-making

\section{INTRODUCTION}

Followers contribute significantly in collective, leader-spurred endeavors. However, extant literature either obscures or demotes follower contributions. The little literature that acknowledges the contributions of followership is de-contextualized (Benson, Hardy, \& Eys, 2016; Blom \& Alvesson, 2014; Burak \& Bashshur, 2013; Carsten et al., 2010; Junker \& van Dick, 2014; Kelley, 1998; Leroy, Anseel, Gardner, \& Sels 2015; Sy, 2010). The main critique of leader-centric research is that it excludes followers who undoubtedly contribute to the leadership process.

The followership literature has two foci. The first addresses followership as a standalone topic. The main themes along this include followership identity (Collinson, 2006; Shamir, 2007; Sy, 2010), follower traits and behaviors (Chaleff, 1995; Hurwitz \& Hurwitz, 2015; Kellerman, 2007; Kelley, 1988; 1992; Potter et al., 1996; Zaleznik, 1964), and classification of followership (Chaleff, 1995; Kellerman, 2007; Kelley, 1992; Zaleznik, 1964). The second body of literature is as an integral part of the leadership research within the broad body of leadership literature. The main themes along this line include follower and leader relationship (Maslyn \& Uhl-Bien, 2001; Uhl-Bien et al, 2014;) and upward influence (Uhl-Bien et al, 2014). Each body of literature has its own limitations. Treating followership as an integral part of the leadership literature addresses the important domain of practice as a fringe or peripheral topic, whereas addressing followership as a standalone area has the risk of decontextualization or decoupling. As is the case with research on leaders or leadership, the research on followership is not sufficiently situated in the followers' 
unique characteristics and differences of practice settings. For example, classification of followership, which is the dominant line within the followership literature, rarely accounts for unique characteristics of industries, sectors, organizations, and movements. It is this observation of a research gap that helped us direct our attention to exploring followership in one particular, but common, context.

We recognize that followership and leadership are not dichotomous. They are integral, deliberate and specialized practices within a context of planned or non-planned social accomplishments. It is therefore necessary to examine various, but critical, dimensions of followership to fully understand leadership. For example, understanding how leaders and followers see and define themselves, as well as understanding how these self-definitions develop, change, and are influenced by leader-follower interactions, can offer us unique insights into the drivers of leader and follower behaviors and actions (Carsten, McGregor, Patera, West, \& Uhl-Bien, 2010).

We believe it is useful to examine followers' views on their experiences of following and being led in the context of the workplace to gain insights into follower-leader dynamics. Because of our interest in meaning making, we frame our research questions along three interdependent lines. Our first line of inquiry focuses on the meanings of followership that our research subjects hold. We specifically pay attention to work related identities. The second line of inquiry focuses on how followers enact their beliefs and preferences as they enter into the relationships and the realm of work accomplishments. The third is an examination of followers' sense-making, such as how they interpret and resolve contradictions, ambiguities and dilemmas in their workplace. These three lines of inquiry help us address three seemingly different dimensions of followership while each reinforcing the other lines of inquiry.

\section{WORKPLACE FOLLOWERSHIP: THREE DIMENSIONS}

Followership is defined differently in various scholarly traditions. Positivists adopt a positional perspective of followership in which followers are identified as subordinates or direct reports or in some cases, as rank and file. Shamir (2007) offers a conceptualization that puts followership in three categories, and two of them fall within the positivist perspective. The first is the followers as recipients of leader influence category. In this category, followers usually play a passive role in the leadership process, and are affected by the leader's behavior. The second is the followers as the moderators of leader's influence.

On the other hand, social constructivists conceive followers as social players with unique identity and subject positions that make differential contributions to organizational or collective engagements. Shamir's third category corresponds with this perspective. Followers in this category are considered as a substitute for leadership and as the constructors of leadership.

The follower typologies in the literature largely fail to consider followership according to organizational characteristics or activity domains. We believe followership in sports activities can be differentiated from followership in workplaces. Followership in the military can be differentiated from followership in worshipping activities. Both the positivist and social constructivist categorizations have limitations. We also feel research on followership, apart from focusing on typologies and upward influence making, need to expand. One way this can be done is by examining followership in its organizational context. Another is by examining followers' identities and sense-making strategies. In this research, we hope to achieve both.

\section{Follower Subject Positioning}

According to Davies and Harre (1990), positioning is the discursive production of selves. It is what individuals are in relation to others or how they understand and view themselves in relation to the world. Simply put, it is the intentional or unintentional placement of the self as a participant in any dynamic group situation. The concept of "positioning" as a term has parallels to that of "role" within traditional social psychology yet articulates both a far more fluid and dynamic sense of the multiple "selves" or "identities" of a person (Korobov, 2010).

Subject positioning helps us understand how followers' actions or behaviors are situated in relational (leader-follower) contexts. It emphasizes how followers' actions or performances unfold based on the 
action situation. In other words, followership has diverse meanings, sometimes stressing subordination and other times stressing collaboration. The concept, therefore, is important to help us understand how followers claim or resist positioning such as identity categories, roles, orientations, and beliefs.

One way to view positioning is to examine how followers form and adjust their orientation. Followership is entangled in both the nature of the job and the location of the job itself within an organizational hierarchy. We know from the role literature (Selznick, 1957; Katz \& Kahn, 1966) that followers expect their roles to be defined and explicated as they pursue work accomplishment. So, the question is, how do followers perceive their roles in the organizational hierarchy? For example, within the subordinate role, followership role orientations are defined as the beliefs that individuals hold about the responsibilities inherent in the role, and the types of tasks and behaviors that make followers successful (Uhl-Bien et al, 2014). Role orientations are neither purely state- nor trait-like constructs (Youssef \& Luthans, 2007); rather, consistent with Parker, Wall, \& Jackson (1997), they develop early in life (Kuhn \& Laird, 2011) and evolve over time as individuals gain experience in a variety of environments and contexts.

In the management literature two prominent orientations are identified in analyzing subordinate role orientations. These are "co-production" orientation (i.e., the belief that followers should actively engage with leaders to advance mutual goals) and "passive" orientation (i.e., the belief that followers should remain deferent to a leader's influence and directives) (Baker, 2007; Chaleff, 2009; Collinson, 2006; Howell \& Mendez, 2008; Kelley, 1998; Shamir, 2007).

Followership orientation refers to how employees and managers view or understand themselves in relation to their superior. Orientation can have two dimensions: job and relation. We refer to job orientation as employees' view of their capacity to accomplish an assigned task, and their perception of the scope and depth of the job; hence their personal definition of what it means to accomplish something. Relational orientation refers to the employees' view or perception of what it means to be a junior. In other words, employees gradually adjust their pre-conceived notions as they work with a superior and enact workplace rules.

Another dimension that helps us understand positioning is identity work (Rasmussen, 2012). For example, Collinson (2006) conceptualizes followership in three identity categories: conformist selves, resistant selves and dramaturgical selves. The conformist selves refer to the disciplined individuals that seek to follow the leader's will in both a positive and negative interpretation. The resistant selves describe followers that leave an organization or voice up against organizational authority. These individuals often help to visibly clarify the actions of management, serving as a way for followers to construct identities they feel more comfortable with than what the organization prescribes. The dramaturgical selves are a response to the increased use of auditing in organizations. The result is employees that are constantly aware of themselves and hence perform a specific form of impression management (Goffman, 1959).

\section{Follower Enactment}

Enactment theory is applicable to life in general, organizations, and the process of self-formation in particular. Employees are constantly engaged in self-formation within the organizational context. According to Eisenberg (1986), this formation occurs in two different ways. Firstly, they achieve stability through enactment of interaction cycles, and secondly through the development of rules for appropriate behavior. Enactment theory can be seen as a process whereby people achieve continuity and coordination, which requires rules and roles to integrate multiple activities together. Enactment theory gives a rationale for distinguishing strategic and routine behaviors. Much enactment is scripted. People employ routine communication plans when they can; when they cannot, their ability to devise new plans is crucial to their success. In practice, a lot of what occurs on behalf of an organization is routine, scripted, and random rather than strategic (Heath, 1994). Weick (1995) uses the term enactment in a more comprehensive way. He

argues that when people act, they bring structures and events into existence and set them in action. Such enactment not only brings structure and action, it also imposes limitations upon the system to avoid issues or experiences. 
Followers also enact roles and identities (Weick, 1995), and hence they continually subject position themselves. According to Weick (1995), "People or organizations produce or construct the environment they face. They act and in doing so create the materials that become the constraints and opportunities they face" (p. 31). He argues that enactment results because people are conscious of relationships. Members of an organization cannot separate themselves as an individual or a member of the organization when imposing meaning upon themselves, other actors, and the environment. Working in an organization reflects a person's products, services and activities.

Follower subject positioning and enactment, such as influence attempts, have significant implications for follower performativity and follower-leader relations. We know from the Leader-Member Exchange (LMX) literature that a follower's perceived quality of relation with the leader enhances the former's commitment to the leader or work. Consequently, the leader's trust in the follower increases, which results in leader and organization actions that contribute to follower empowerment. Spreitzer (2007) identifies two types of empowerment: socio-structural and psychological. We present here only psychological empowerment which is closely related to positioning and enactment. Psychological empowerment refers to a set of psychological states that are necessary for individuals to feel a sense of control in relation to their work. Rather than focusing on managerial practices that share power with employees at all levels, the psychological perspective focuses on how employees experience their work. This perspective defines empowerment as employees' personal beliefs about their role in relation to the organization. Spreitzer identifies four dimensions of psychological empowerment. The first is meaning, which refers to the fit between the needs of one's work role and one's beliefs, values and behaviors (Hackman \& Oldham, 1980). The second is competence, which refers to one' belief in their self-efficacy or capability to perform work activities with skill (Bandura, 1989; Gist, 1987). The third is self-determination, which refers to a sense of choice in initiating and regulating one's actions (Deci, Connell \& Ryan, 1989). This reflects a sense of autonomy or choice over the initiation and continuation of work behavior and processes (e.g., making decisions about work methods, pace, and effort) (Bell \& Staw, 1989). The last is impact, which refers to the degree to which one can influence strategic, administrative, or operating outcomes at work (Ashforth, 1989).

\section{Follower Sense-Making}

Subject positioning and enactment are closely tied to how actors (employees and managers in this case) sense make their environment (other actors such as their managers), policies, processes, and expectations. According to Weick (1995), sense-making is simply "the making of sense" (p. 4). It is the process of "structuring the unknown" (Waterman, 1990, p. 41) by "placing stimuli into some kind of framework" that enables us "to comprehend, understand, explain, attribute, extrapolate, and predict" (Starbuck \& Milliken, 1988, p. 51). Sense-making is the activity that enables us to turn the ongoing complexity of the world into a "situation that is comprehended explicitly in words and that serves as a springboard into action" (Weick, Sutcliffe, \& Obstfeld, 2005, p. 409). Indeed, sense-making involves an articulation of the unknown.

Sense-making fulfils three cognitive and non-cognitive functions. One is as a meaning-making process through which people work to understand issues or events that are novel, ambiguous, confusing, or in some other way violate expectations. A central aspect of this process is noticing and interpreting based on various streams of cues, some solicited and others unsolicited. When people tell workplace stories, it is an aspect of sense-making. The second function is organizing. People only make meaning of their chaotic or complex environment through order. It is an activity central to organizing (Maitlis \& Christianson, 2014). The third is accomplishing. People act based on their sense-making. This can happen in real time (ongoing) or retrospectively (Weick, Sutcliffe, \& Obstfeld, 2005).

Most writers use the word sense-making in the context of what actors think and do to reconcile a gap between expectation and reality. They use crisis situations as examples. However, when employees are faced with a new reality (e.g., a new assignment, leader ambiguity, relational uncertainty, etc.), it is inevitable that employees try to make sense (interpret the new reality and choose a course of action). Employees do so in various sense-making types. It is obvious that an employee's sense-making is largely not verbalized. They engage in a stream of sense-making activity both during and after routine and non- 
routine activities. When sense-making is verbalized (e.g., through internal reflective sessions or personal journals), it reveals lots of plausible accounts of the sense maker's experiences. However, when it is not verbalized, it is only through research like this that we can get into the sense makers' accounts of their experiences. Such accounts may not be as plausible as when they are retained during or immediately after doing the sense-making. Therefore, such retrospective sense-making has a limitation in this regard.

\section{METHODOLOGY}

Adopting a conceptual framework based on the theories of sense-making and subject positioning, the study examines early career employees' experiences of followership. We operationalize subject positionality as a constituent of orientation and identity work. Orientation focuses on how followers view their relation with the leader and their job. Identity work focuses on how followers wish to be identified in relation to their job. Followership enactment constitutes routine behaviors and strategic behaviors. Routine behaviors refers to regular, repetitive actions with the aim of task completion without taking into account its benefits to one's future career or position, whereas strategic behaviors focuses on the follower's action grounded in one's future career or position aspiration. Lastly sense-making refers to how participants interpret action situation including expectations, ambiguities, contradictions, and dilemmas.

The broad methodology adopted in this research can be summarized as qualitative and interpretivist while the grounded (informed by grounded theory) sense-making methodology guides the process of constructing the meaning of followership through the lens of what research participants recall and notice retrospectively. The study went through two layers of research participant selection and data generation. The first phase, called the context mapping interview, focused on globally engaging MBA students in reflecting on their followership experiences. In total, 22 participants completed a 26-question self-interview and construction of a personal follower narrative based on their responses to the self-interview questions. Both the self-interview questions and narratives were intended to obtain the subjects' personal accounts of their thoughts and actions during a particular period of a new type of (nonroutine) engagement. The personal followership narrative helped to explore the participants' followership contexts and how they generally characterize their followership in relation to the leadership context in which they operate.

The second phase, which is named sense-making interview, is a follow-up data collection activity. Based on phase 1 data, a semi-structured interview was conducted with 15 subjects. The subjects held a variety of positions (e.g., human resource associate, associate director in alumni office, quality assurance associate at a bank, information technology planner at a school district, ads sales associate at a newspaper publisher) and tenures (i.e., less than four months to 5+ years). Informed by the sense-making methodology (Dervin, Foreman-Wernet, \& Lauterbach, 2003), the interview questions focused on a person's movement through time and space by querying follower-leader relation structures, patterns, struggles, and trajectories. Questions were recursive in that they focused, surrounded, or triangulated around relational challenges and opportunities.

Data analysis involved summarizing the initial self-interviews and carefully listening to each audio from the sense-making interviews. We listened to the interviews using the pre-set analytic questions that correspond to follower subject positioning, follower enactments and follower sense-making themes. Using the positionality-enactment-sense-making line, we read the initial summaries and the verbatim-like notes in iterative fashion - going back and forth - in search of patterns and idiosyncrasies. While organizing the raw data, multiple sense-making strategies were deployed including memoing. One of the researchers was able to record audios of sub-verbalized and self-talks on emerging thoughts and interpretations. The audios were listened to and used to supplement patterns that emerged along the three overarching analytic questions. Inter-coder interpretative convergence and divergence was also used to maintain data analysis rigor. 


\section{FINDINGS}

We report the findings through the voices of three research subjects, each representing a sub-group of the research sample. The findings reveal some meanings of the three dimensions of workplace followership that we examined and the need for more data to further look at the meanings. Followers understand their power, agency, and contributions within the constraint of authority relationship in their workplace. Their sense-making is based mainly on the cues they gather from their interaction with the leader. However, their action may not be congruent with their interpretations of the new reality. Followers in most cases engage in both routine and strategic enactments though one or the other may dominate depending on the unique circumstances of the follower (See Table 1).

\section{Michelle}

Michelle was a human resource associate at one of the branches of an insurance company. She reports to the human resource manager and has no employees reporting to her. Most of Michelle's interactions are confined to her manager and she meets with her on a daily basis. As a direct line of communication, Michelle gets a lot of her direction from the manager.

On a day-to-day basis I communicate with the HR director...Every morning we have a meeting.... She basically assigns me different duties and follows them up on different cases...I have my job and she oversees what I do... if I have any issues and questions I basically throw them at her... we communicate if there are issues...she is definitely my direct line of communication. I get a lot of direction from my HR manager... as a follower I listen to a lot of what she has to say on certain things. I learn from her. My boss reports to individuals in Philadelphia. I report to her so any thing I do is close to her. I know who to communicate with, and that is my director. I don't normally communicate with the people in Philadelphia because she is my direct line of communication.

From the above quote, we learn how Michelle's formal relationship with her manager is established and her views of the relational structure. The quote reveals a traditional, hierarchical type of subordinatesuperior relationship. Workplace assignments are given down and its implementation is supervised. We see proximity of a follower to the leader within a hierarchically established system. Michelle's subordinatesuperior proximity remains unaffected because she communicates daily with her boss. As a result, Michelle finds no issue with an authority relation. In addition to proximity, we also see easy resource dispensation. We find evidence of this when Michelle claims that the manager is her singular source of direction, clarification, and feedback. As a result, the manager is not only authority, but also authoritative by being a provider of information and knowledge. In Michelle's view, having someone who is experienced, knowledgeable, and able to translate the experience and knowledge into direction, is necessary for an employee to engage in a productive way.

In the data, we also see Michelle's tacit approval of boundary and boundedness. This is evident when she says "a fixed hierarchy is useful." The fact that employees know who does what, in her views, "keeps arising problems in check." Such a system, and the authority relation with her manager, allows her to receive directions reliably and follow through with them. She also claims the effectiveness of the system, and hence her commitment to implement directions and instructions. Here we see the discourse of loyalty, faithfulness, clarity, and commitment.

In her description of subordinate-superior communication, we see how Michelle defines her role through two seemingly contradictory, but complementary, processes. She says she is an ardent listener and always ready to get messages right. If initial directions are not received well, she requests clarifications. She sees herself as a subordinate committed to doing work with clarity, and establishes it through unfettered access to her manager to ask questions. She also describes herself as a challenger. She recalls one time when she and the manager disagreed on something which led to subsequent actions, including a threesome meeting with a senior manager. 
In the data, we also see Michelle's explicit approval of the manager's leadership style. She refers to the manager as a leader who knows how to handle her subordinate, which is keyed in the scope of autonomy she is granted. In other words, the manager, not only meets her demand for knowledge and guidance, but also lets her work independently. She describes her ability to define her work and make certain decisions as a mark of autonomy. She is satisfied with the level of access she has to opportunity and support. She recognizes the impacts of the manager's style of leadership, particularly her approachability, willingness to answer questions, and provide autonomy. She interprets the autonomy as a sign of trust and source of growth which ultimately boosted her self-esteem.

I like a lot of autonomy when I do my work. When I have a project, I like to be in control, and she sees that and she gives me that freedom to be in charge if she knows I am able to do it. Being able to come to your supervisor with any concerns....any ideas. A good supervisor is who is approachable...I never had an issue going to her...she calms me down...I don't get that negative response that I am afraid to... I think that is very important. She would rather have me ask questions than not. She feels I am engaged when I ask questions. Leaders have a lot of influence over their followers. If I were to be a leader, I would follow the model of my director. I have learnt tremendously under her leadership. She doesn't take all the credits. She puts all the credits where credits are due.

As far as identity work is concerned, Michelle sees herself as a work in progress, who is open to change and new ways of being. She envisions such a project through a commitment to her leader by listening and executing directions as faithfully as the leader wishes. Similarly, she envisions new ways of being through a commitment to her work--a devotion to learn how to do things better which is anchored in her ability to asking questions. This is an allusion to her conformist self-identity. She is compliant in conforming to the directive of her authority as long as she has the trust and autonomy to complete the tasks.

A material in the interview which provides some insights into how she views her workplace identity is present in two of the interview segments. In one segment, she portrays a generational distinction. While justifying why she connects so well with the manager, she claims that the manager is "a mother of a daughter who is at my age." While such a portrayal is purely age-related, it has implications for generational differences because she explicitly made a reference to the gap between the two ages. This might also be related to the boundary discourse stated earlier. Boundary is not only structural; it can also be identity.

In another segment, she also offers her identity revealing perspectives through a distinction between her co-workers' manager and her own manager. She states:

At the underwriting department, the manager is very old school; he is not open to new ideas. It is tough. I see a lot of backlash because of that type of relation between him and his subordinates.

Here, it is very important to note that despite the age and generational difference, she does not see her boss as old school like her co-workers' manager. She views her coworkers' manager as old school due to his lack of openness to "new ideas" by subordinates. In contrast, she describes her manager as old enough, but capable of managing the age gap.

Michelle's sense-making strategies can be gleaned from the various ways she describes her routine work. A major way for her to learn is through acting and seeing what emerges. For example, her stories of communication reveal her reliance and emphasis on the manager's cues for direction. The more she communicates with the manager, the more she recognizes her limitless access to information about her work.

My manger is not annoyed by repeated questions, but I also try to get things right in our first meeting to avoid repeated questions...when things are vague... when I am not 
comfortable, I try to learn to do it on my own... but don't hesitate to ask questions... if I have questions

Michelle enacts mainly routine behaviors. She is more preoccupied with the day-to-day than the long term. For example, in the interview, she did not make any efforts to make connections between her workplace behavior with her future career aspirations.

\section{Annette}

Annette was an assistant director at an alumni office, whose main responsibilities were fundraising and communication. She reported to the director of the alumni office. Personnel had been restructured a couple times since she came to her position. The change happened in the director position. Her work required her to interact with the director and another co-worker, and they also worked closely with several other offices on campus.

Annette thought she was initially committed to her work, but that changed because of the director's leadership style. She says, "your supervisor can make or break how much you are committed." She recalls her initial commitment gradually diminishing and merely complying with the director's requests. She also said she never did things "out of the line" emphasizing her respect for hierarchy of authority. It appears from her answers to the interview questions that both her initial commitment to work and compliance was driven by her concern for job security.

The relationship with the director (the last person to oversee her work) gradually became constrained. At the beginning, Annette used to propose exciting ideas to the director. She would also attempt upward influence making by challenging the director in what appears to be an interest in co-production. The director would listen, but decisions never reflected Annette's interests and goals. She found out that the director makes decisions single handedly. Annette said:

She decided everything to do things her way. I don't think my supervisor would understand my side of things...even if I explain to her. I don't think she would understand it. One day, I had a hard conversation with my boss, and coming out of that conversation, I was convinced that I should do whatever she asks... and I should not be miserable forty hours thinking that...I convinced myself to deal with it and find my own ways of dealing with my feelings and emotions.

Gradually, that led her to a sense of being ignored. She felt she was just a mere implementer of her director's vision. She came to understand that there was little meaning in challenging the director, and she eventually ended up leaving her post because she felt she "was not appreciated."

Annette identifies the director as authority, but not authoritative. She assesses the condition as a traditional authority hierarchy, and self-positions herself in the subordinate role. She enacts her subordination through the emotional distancing of herself from the role and aims not to actively impacting the leader's agendas by contributing her personal thoughts or ideas. Ultimately, this emotion work led Annette to the conclusion that upward influence attempts are a waste of time. Though the director had the authority, she did not provide any psychological empowerment.

I kept being as agreeable as possible. I didn't express anything that amounts to disliking the job or my supervisor. I tried to be pleasant. I think it was hard to do for me. I put aside my emotions and feelings.

While enacting the subordination role, Annette maintained transitory relationship behavior. The transitory behavior was to appear a committed employee who is "agreeable" and "pleasant." In a way, she enacted a transitory behavior which can be considered strategic at least at a personal level.

Another theme running through the interview is the leader-follower gap. According to Annette, the director's personality and leadership style, was incompatible with her expectations, personality and 
follower style. Two ways Annette reveals such a gap are when she describes the director as not "personable" and "very private." As a result, she found the director unapproachable despite attempts to develop a professional relationship. Annette even regrets being too "challenging" to her, which might have worsened her work condition. Second, she feels the director is too maternalistic, and sees that as "controlling." One of Annette's criticisms was evident when she said: "personality pays a huge role, how the supervisor asks you to do something matters a lot." For example, if she says, 'I need this report in two hours' puts a lot of pressure on you."

One of the main themes from Annette's interview, which has a significant implication for leaderfollower relationship, is her explicit reference to the director's competence. Offering an evaluative opinion of her director, she revealed the director's apparent "inadequacy" in social skills. "My supervisor lacked interpersonal communication skills. She relied on me on things such as emails and social media." It is understandable that followers' judgment of leaders' competence shapes the former's level of reliance on or obedience to the leader. Annette might have sensed a contradiction; on the one hand, her director relied on her as far as electronic and social media communication is concerned. On the other hand, she felt she had no voice in decision making. It is also true that when subordinates judge their superior poorly on expertise, their respect and trust may not be strong. Annette's views of the director's competence sharply contrast Michelle's. While Michelle viewed her manager as competent and experienced and relied on her for guidance, Annette adopted the opposite view. It is also possible that because of such a judgment, Annette might have overstepped her boundaries, resulting in the director's decision to "tighten" her control. Whatever the case may be, Annette as a follower felt her boss was "incompetent." As a result, she felt the work was not worth pursuing because, in the end, it was not fulfilling.

Annette's identity work resembles Michelle's identity work in some respects. Like Michelle, Annette views the divide between her and the director mainly through a generational lens, describing her as maternalistic. While age is a factor for their differential worldview, their skills gap in media communication is likely a contributory factor. There are also key differences. For example, Annette's identity reflects the resistant selves while Michelle's identity resembles the conformist selves (see Collinson, 2006 for the distinction between resistant selves and conformist selves).

As far as her retrospective sense-making is concerned, she interprets the director's personality, ambiguity, and single-handedness in decision making as the cause of her non-conducive work condition. She learned in the process that the situation was unchangeable and cites this as the reason for her leaving the position. According to Weick, people learn about situations by acting in them and then seeing what happens (Weick, 1995). Children often learn the rules in a family by pushing boundaries and then looking for the point at which they get reprimanded. Annette seems to have learned from her repeated attempts to "challenge" the director. She came to realize that such attempts are futile. Some segments of the interviews (including her tone during the responses) reveal experiences of failed influence making. When she uses the phrase "miserable 40 hours," it is descriptively revealing of what she feared in her workplace.

Annette enacted strategic behaviors and focused on long-term goals rather than short-term ones. This is evident in what she said about pulling away. She presents herself as a subordinate who "pulled away"someone who retreats strategically to facilitate an exit strategy. While she externally positioned herself as well-suited for the role and ready to pour her emotion and effort to the work, internally she felt her director was not up to the expectation of the position. She gradually focused away from work to her personal wellbeing. In such cases, when emotion is at stake, work becomes secondary. There was a sacrifice to be made: leaving her job. In such cases, followership becomes an act of self-preservation, instead of a means of commitment to work and the institution. 
TABLE 1

SUMMARY OF FINDINGS

\begin{tabular}{|c|c|c|c|}
\hline $\begin{array}{l}\text { Research } \\
\text { Subjects }\end{array}$ & Subject Positionality & Enactment & Sense-Making \\
\hline Michelle & $\begin{array}{l}\text { Positioned oneself as recipient of } \\
\text { directions and the director as a } \\
\text { source of direction (e.g., "My go- } \\
\text { to person is always my boss.") } \\
\text { Positioned oneself in } \\
\text { subordination to the director } \\
\text { within the context of the } \\
\text { organizational hierarchy } \\
\text { Positioned oneself as a trusted } \\
\text { associate director }\end{array}$ & $\begin{array}{l}\text { Predominantly enacted } \\
\text { routine behaviors (e.g., } \\
\text { regular communications } \\
\text { with the leader to ensure a } \\
\text { proper flow of directions } \\
\text { and feedback) } \\
\text { Enacted the conformist self } \\
\text { (while maintaining a certain } \\
\text { degree of the subordinate as } \\
\text { a challenger attitude) }\end{array}$ & $\begin{array}{l}\text { Meaning making: By paying } \\
\text { attention to instructions and } \\
\text { feedback, she tried to } \\
\text { understand expectations and } \\
\text { procedures } \\
\text { Organizing: tasks are } \\
\text { prioritized and ordered } \\
\text { based on where they come } \\
\text { from } \\
\text { Accomplishing: considers } \\
\text { herself skilled and high } \\
\text { accomplisher dedicated both } \\
\text { to her work and the director }\end{array}$ \\
\hline Annette & $\begin{array}{l}\text { Positioned oneself as a self- } \\
\text { preserving associate director } \\
\text { (within the context of working } \\
\text { with a director who is not } \\
\text { compatible with her beliefs and } \\
\text { style) } \\
\text { Positioned oneself as a happy } \\
\text { and dissatisfied associate director } \\
\text { Maintained affirm belief in the } \\
\text { subordinate as a challenger } \\
\text { (though that belief backfired on } \\
\text { her relationship with the director } \\
\text { Positioned oneself as a recipient } \\
\text { of directions from a director who } \\
\text { is top down-minded and } \\
\text { incompetent. }\end{array}$ & $\begin{array}{l}\text { Predominantly enacted } \\
\text { strategic behaviors (while } \\
\text { secondarily maintaining the } \\
\text { enactment of routine } \\
\text { behaviors) } \\
\text { Enacted the resisting self }\end{array}$ & $\begin{array}{l}\text { Meaning making: relied } \\
\text { little on the director to } \\
\text { interpret what and when to } \\
\text { do something though she } \\
\text { faithfully executed } \\
\text { directions } \\
\text { Organizing: Kept herself at } \\
\text { a reasonable distance from } \\
\text { the director } \\
\text { Accomplishing: believed } \\
\text { she was skilled and even } \\
\text { more competent than the } \\
\text { director }\end{array}$ \\
\hline Jeff & $\begin{array}{l}\text { Positioned oneself as a partner } \\
\text { and a collaborator (while } \\
\text { accepting the director as one who } \\
\text { has the final say in times of } \\
\text { extreme disagreements). } \\
\text { Positioned oneself as a trusted } \\
\text { employee (e.g., "My boss trusts } \\
\text { my judgement.") } \\
\text { Positioned oneself as an } \\
\text { employee who benefitted from a } \\
\text { director who is compatible and } \\
\text { trusting (e.g., viewed the director } \\
\text { as a mentor, respectful, and non- } \\
\text { manipulative.) }\end{array}$ & $\begin{array}{l}\text { Enacted both routine and } \\
\text { strategic behaviors (e.g., } \\
\text { based on feedback from the } \\
\text { director, he became more } \\
\text { aspirational for a future } \\
\text { leadership role at the } \\
\text { department) } \\
\text { Enacted the conforming self }\end{array}$ & $\begin{array}{l}\text { Meaning making: direct, } \\
\text { open, constant } \\
\text { communication channels; he } \\
\text { has and takes the liberty to } \\
\text { discuss uncertainties with } \\
\text { his boss; he sees this as } \\
\text { seeking guidance and } \\
\text { mentorship } \\
\text { Organizing: he emulates his } \\
\text { boss's style and work ethic } \\
\text { Accomplishing: he is } \\
\text { allowed to set his own goals } \\
\text { and that gives him } \\
\text { autonomy; enjoys what he } \\
\text { does and for this, he gives } \\
\text { credit to his boss }\end{array}$ \\
\hline
\end{tabular}




\section{Jeff}

Jeff is an ads sales employee in a media organization that owns local radio stations and newspapers. He does print and digital billboards, radio ad sales, advertising, and marketing for the organization. Jeff works under the director of advertising and frequently meets with him for assignments and work review. But Jeff characterizes the work as mostly independent because each ads employee decides his or her own strategies once the assignment is given. His director looks at the "numbers" of sales and places an emphasis on the results of the work.

Jeff's relationship with his director was impacted and shaped by a unique relationship. "We text back and forth. You know, sometimes, you know, we'll text, you know, he's a big sports fan. So that's where we first hit it off." This, obviously, reveals a social connection that transcends the work relationship. The way they address each other, and the purpose of their communication is significantly shaped by the social dimension of their ties. This is an important context to look at the workplace relationship between Jeff and his director.

There is an element of the servant mindset in Jeff's understanding of his work. The servant subject positionality is present in the way he describes his customers and business values. For him, the key is to adjust oneself in terms of satisfying customers. He believes such a mindset, is not only necessary to meet sales goals, but also to be viewed positively from one's director. His reference to money, when saying "money is money" might sound that he is money-oriented. If that is true, we find a contradiction between his service subject positionality and money-making interest, though one might argue that the two are not inherently contradictory.

I would say, I mean, everything that's given to us, I comply. The way I look at it is working in sales ...money is money. Sometimes you have to do deals that you're not going to have your manager right there. Or, sometimes you have to take it on your own.

His self-positionality can also be described in terms of an employee who is autonomous, empowered, thriving and comfortable. For example, Jeff says, "you create your own agenda for the day", alluding to the presence of autonomy in his work. He enjoys the work, perhaps, because there is a good fit between his interest and the job, and the way the job was designed for him. Partly because of the social dimension of their relationship and partly because of his performativity (based on his anecdotal claims) Jeff reveals the director trusts him and that has given him a sense of autonomy and empoweredness. He views himself as a well-positioned employee who is trusted by the director and being groomed for a possible future director position. Jeff feels the director has created a "perfect" environment for learning and working to his fullest potential. His spirit was uplifted by the director's direct encouragement, which was apparent in Jeff's use of phrases such as: "He often tells me that I am a future director of the department"; "...the director is gearing me towards a leader..."; "He sees a lot of himself in me...younger version"

Jeff's follower positionality was an identity work that continued from previous employments. Right at the beginning of the interview, Jeff emphasized that his current role orientation evolved from his previous job at a casino, where he worked as a customer service representative:

...because I believe my past experience, you know, brought me to where I'm at right now. That's why. I mean, it was pretty much customer service. Now the casino and my customer service [experience], you know, translate into what I do now. And that's, you know, that's the number one thing that I take pride in.

When Jeff was asked if he became a different kind of employee or gained a different identity as an employee after he came to the media organization, he responded by saying he came with a "different mindset." He added by saying that he quickly embraced a "business mindset."

Arguably, Jeff's positionality can also be summarized in one phrase: a partner in subordination. In other words, although Jeff enjoyed the smooth and cooperative relationship with his director, it is not deniable 
that he also viewed himself a rank lower than his superior. Such a superior-subordinate viewing of the relationship was evident in the way he sought support from the director.

Jeff's sense-making reflects both strategic and routine behaviors. Jeff makes sense of the followership required of him through the daily interactions and communication with his director. He can discuss his goals and responsibilities, and feels his director's expectations are clearly defined. His director gives him just enough directive and structure to make him feel confident taking the initiatives. This gives Jeff the space needed to explore the boundaries of his followership. For example, when negotiating prices for advertisements, Jeff discusses how the director may not always agree with his decisions. However, he believes that he can compromise to address such conflicts. Through such a process, Jeff is able to understand where his expectations as a follower begin and his autonomy ends.

The director's leadership style seems to present the sense-making framework for Jeff's followership. That means Jeff can only understand his followership style within the context of his leader's expectations and behavior. Initially, Jeff understood that his previous roles were not right for him based on the leadership style. This helped him to better understand himself and his followership identity. Not only was he able to learn about his own followership identity from those conflicting experiences, he was able to form ideas about what leadership style he was best suited to follow. He realized he needed a leader that provided him more autonomy, responsibility, trust, and mentorship. Through the daily interactions between him and the director and the productive conflict that ensued, he was able to make better sense of his followership style. His identity work took place in different workplaces, but it appears that his current work provides him an empowering and fulfilling experience to enact his ideal followership style.

\section{DISCUSSION}

In this section, we revisit our initial questions concerning subject positionality, enactment of environment, and sense-making. We first address the more descriptive question, namely positionality, and then the more analytical questions, that is enactment and sense-making.

The data reveals three categories (not necessarily mutually exclusive) of follower subject positionality. These are the dependent actor, the empowered actor, and the self-preserving actor. In the dependency positionality, respondents revealed a high regard for authority. Leadership is acknowledged as a source of authority, through directive giving and final decision making, and as a source of knowledge, final verdict, or final verification. As a result, there is a great deal of deference. Subjects in this category enacted dependency and claimed the position of the dominated while acknowledging power hierarchy with the superior. The dependency view does not suggest the subjects are unempowered. It simply points to the subject's reliance on the leader. The reliance in some cases is for information, including knowledge, and in other cases, it is for decision making.

The second, which can be referred to as empowered actor positionality, in which the respondents acknowledge a relationship and work environment congruent with their desire for growth and productivity. Using the psychological empowerment framework, which looks at four dimensions, namely meaning, competence, self-determination, and impact (see Spreitzer, 1997), we can show how empowerment existed in the discourse of the two subgroups. First, they find the work compatible with what they wish to do, showing that their job is meaningful to them. Second, they believe they bring adequate knowledge and skills that meet the demand of the work, and they do not reveal any negative judgments or poor evaluations from their boss. On the surface, this points to competence. Third, they all reveal that they have autonomy and their inputs is considered. For example, Michelle frequently mentions the word "autonomy" during the interview, and this corresponds with the self-determination dimension of psychological empowerment. Fourth, they are confident that they positively contributed and advanced their manager's or director's visions and agendas, and this corresponds with impact.

The third, which can be referred to as self-preserved positionality, is a relationship and work environment that the respondents reveal as noncongruent with what they deem to be opportunity for productivity and self-growth. For example, Annette, who believes assertiveness and co-production as a desirable behavior of a good follower, regrets the absence of a condition that embraces assertiveness and 
co-production. Research subjects reveal constraints (both leader and structural) that limit their ability to autonomy as an independent decision maker. Although she brought such the-good-follower mindset to her workplace, she gradually realized the director was not compatible with such a mindset. Hence, she gradually resorted to a passive deference position as a strategy.

Annette gradually enacted, at surface and observable level, an identity that reflects submission to domination. However, at a deeper, but unobservable, level, she implemented resistance. This is an aspect of identity work which, in Collinson's (2006) words, can be referred to as the emergence of a resistant self.

Annette's description of her work condition reveals the tension between the desire to have autonomy (and the existence of such an autonomy to some extent), on the one hand, and the workplace reality that limits a subordinate's voice, on the other hand. While she acknowledged that she had autonomy in some cases, for example, in defining her specific operational tasks, she felt her power was too limited. The autonomy was not significant enough to take substantive initiatives. The fact that Annette had some level of autonomy may sound she operates under the condition of structural empowerment. On the other hand, her boss's approach, namely being too paternalistic, in Annette's eyes, felt like controlling. It is commonly known that, in such cases, the desire for managerial control emanates from the belief that the subordinate is inadequate to handle responsibility. Whether this is true or not, the fact that there was a lack of trust in Annette's competence, is not possible to infer from the data. What is evident in the data is the lack of psychological empowerment. At least in three of the psychological empowerment dimensions, namely, meaning, self-determination, and impact, Annette had no psychological empowerment. She felt there was no fit between the needs of her work role and her beliefs, values and behaviors (Hackman \& Oldham, 1980). She was denied the space making initiatives and regulating her actions (Deci, Connell \& Ryan, 1989), which reflects the presence of constraints in regards to choice over the initiation and continuation of work behavior and processes (e.g., making decisions about work methods, pace, and effort) (Bell \& Staw, 1989). Lastly, her sense of making impact (Ashforth, 1989)-i.e., the degree to which she could influence administrative or operating outcomes at work-was little or none.

As far as multiple identities are concerned, in the Jeff's subgroup, we see the follower as a co-enactor, friend (out of work), and leader ("I am my own boss"). While we see more of followership as co-production, we see less of followership as a subordination in Jeff's subgroup. However, in Annette and Michelle's subgroups, follower as a subordinate is highly prevalent. The notion of the follower as co-producer is minimal though they acknowledged the presence of opportunities for upward influence.

A detailed analysis of the trajectory of the evolution of subject positionalities is not possible from the current data. However, a closer examination of the data reveals that followers' re-orientations or adjustments of positionality occur remarkably. Both negative and positive relational experiences and how they make sense (interpret) of the experiences shape the follower reorientation adjustment. For example, both Michelle and Jeff, because of their positive experiences, adjusted their orientations from passively complying to actively shaping the meaning of work and being committed. Jeff and Michelle's leaders encouraged expressing ideas and challenges, which in turn, increased their confidence. On the other hand, Annette's reorientation from active co-production to passivity occurred when her leader diminished her ability to challenge and question.

Apparently, both Annette (negatively) and Jeff (positively) reoriented their followership. In other words, they reoriented their position or role because of the situation that was different from what they had known before. The literature on identity work shows that employees' sense of self in relation to work, and the person with or under who they work, evolves.

Increasingly, however, individual identities, even among professionals, are conceptualized as inherently precarious, malleable, and ongoing enterprises that require active and ongoing construction or "work." Here individuals are viewed as engaging in variety activities to build, revise, maintain, repair, and otherwise craft their identities. In this way, identities not only shape values, beliefs, feelings, and behaviors, but also serve as personal projects. People both enact and act upon their identities (Lepisto, Crosina, \& Pratt, 2015, p.12). 
It is also evident from the findings that the research subjects have a deep sense of working with their manager or director. In other words, the way they respond to questions reveal deeper meanings related to the importance of quality of relationship. Even in the absence of quality relationship, perceived quality relationship shapes one's level of commitment to the leader. As described by Graen and Uhl-Bien (1995), strong relationship quality between a leader and a follower is a key element in effective leadership and its outcomes. Followers who perceive a strong relationship with the manager will be more comfortable sharing their ideas and critiques with the leader because they are confident that their relationship allows for such behavior (Afsar \& Saeed, 2010; Brower, Schoorman, \& Tan, 2000). We see this in both the Michelle and Jeff subgroups.

Followers who perceive a poor-quality relationship with the leader, on the other hand, will likely be less willing to voice, and less confident that their voice behavior will be positively received. Lower quality relationships are characterized by a lack of trust, such that even followers with stronger co-production beliefs may be less willing to make themselves vulnerable (Maslyn \& Uhl-Bien, 2001). Furthermore, they may perceive that voicing their opinions may further diminish an already weak relationship with the leader (Carsten et al., 2010 p. 213). We see this in Annette's subgroup, who gradually resorted to the silent resistance mode because of the low relational quality.

While the Michelle and Jeff subgroups had positive relationships with their superiors, and hence benefitted from such a relationship, the Annette subgroup had a less positive relationship and hence were not able to have an empowering work environment. This is congruent with what Weick says: "People or organizations produce or construct the environment they face. They act and in doing so create the materials that become the constraints and opportunities they face" (Weick, 1995, p. 31). While Michelle and Jeff were able to enact their identity in a more congruent way with the identity of their bosses, Annette was not able to enact her identity at least in such a way that director would accept. As a result, Annette contributed to a constrained environment while Michelle and Jeff co-created (with the leader) an opportunity environment.

\section{CONCLUSION}

Our research reveals that employees' meanings of followership varies along subject positionality and sense-making. The findings deviate from the literature which categorizes followership only along personality differences and leader styles. The findings also indicate that followers understand their power, agency, and contributions within the constraint of authority relations and the realms of workplace engagement possibilities, and opportunities for future career growth.

The most salient views of the research subjects are their views of hierarchy and boundary. They position themselves in subordinated (lower to the person who oversees their work) roles and status which conforms with the norm and formal rules of many workplaces. Such an endorsement of hierarchy and boundary seems contrary with their views of autonomy. They all indicated they value autonomy in their workplace. Their views of hierarchy and boundary align more with the positivist tradition of followership.

Our research subjects' acceptance of asymmetrical power relationship is both directly and indirectly evident in the data. For them, hierarchical relationship as a structure is necessary to overcome confusion, ambiguity, and complete their assignments successfully. The leader is a source of clarity and resources. Reciprocity or co-influence is not necessarily an effective leadership. They repeatedly allude to the fact that they are effective followers even in the absence of any assertion that the relationship is based on coproduction. It is abundantly evident that they were comfortable with boundary and relational distance. However, they also value, among other things, a quality follower-leader relationship.

Given the respondents tacit belief that boundary and distance is not an impediment to follower-leader relationship, it is possible to infer that their views of relationship are largely instrumental and task-related. Our research corresponds with what theories of power relations show about actors who operate with differential authority levels. However, research on the role of followers as co-producers and writers who specialize in followership argue that symmetry or reciprocity correlates with productivity or effectiveness. Kelley, for example, suggests that "instead of seeing the leadership role as superior to and more active than 
the role of the follower, we can think of them as equal but different activities." The position that leaders and followers are equal in terms of their roles is clearly present in the followership scholarship. However, we have no data in our research to support this claim. Rather, we find power dynamics at play. In most of the cases, followers who recognize the differential power relation, and who adjust their workplace role and relationship orientations in accordance with the power difference, seem to be more satisfied with their workplace experiences. Others, as shown in the Annette subgroup, who appear to see the relationship differently, find the workplace experience unrewarding and not congruent with their followership style.

We can conclude, based on our data, that the literature in which followers are depicted as co-producers has two problems. One is a practicality problem. It ignores the view that individuals operate in the context of asymmetrical power relationship. The second is a contextual problem. Even if we say that followers are co-producers, we need to put that assumption in context. For example, senior and junior followers have different capabilities that may allow them to achieve various levels of co-production with the leader based on their experience and adeptness with tasks. Therefore, followership levels, often manifested through workplace tenure, matter in shaping followers' readiness to engage in co-production. Even so, the characteristics of the work goals needs to be considered. For example, when leaders make high-stake decisions, they rarely draw on inputs from all types of followers. Some followers may provide more insight than others due to structural constraints such as time and process.

The study has implications for how we need to take into account contexts of the follower and workplaces. It also has implications for follower performativity and empowerment. By viewing the implications from the perspectives of enabling and constraining forces, the research reveals the need to balance boundary and autonomy. Followers view boundary or hierarchy as a necessary and enabling factor. Boundary helps to mitigate the confusion of leader ambiguity and empower the follower. It is useful for accountability and to exercise their agency within a boundary. However, if the leader is not able to manage the boundary properly, the follower may feel constrained and disempowered by the lack of agency due to fear of burden and accountability.

\section{REFERENCES}

Afsar, B., \& Saeed, B. (2010). Subordinate's trust in the supervisor and its impact on organizational effectiveness. Romanian Economic Journal, 13(38), 3-25.

Ashforth, B.E. (1989). The experience of powerlessness in organizations. Organizational Behavior and Human Decision Processes, 2(43), 207-242.

Baker, S.D. (2007). Followership: The theoretical foundation of a contemporary construct. Journal of Leadership \& Organizational Studies, 14(1), 50-60.

Bandura, A. (1989). Human agency in social cognitive theory. American Psychologist, 44(9), 1175-1184.

Bell, N.E., \& Staw, B.M. (1989). People as sculptors versus sculpture. In M.B. Arthur, D.T. Hall, \& B.S. Lawrence (Eds.), Handbook of career theory (pp. 232-251). New York, NY: Cambridge University Press.

Benson, A.J., Hardy, J., \& Eys, M. (2016). Contextualizing leaders' interpretations of proactive followership. J. Organiz. Behav, 37, 949- 966.

Blom, M., \& Alvesson, M. (2014). Leadership on demand: Followers as initiators and inhibitors of managerial leadership. Scandinavian Journal of Management, 30(3), 344-357.

Brower, H.H., Schoorman, F.D., \& Tan, H.H. (2000). A model of relational leadership: The integration of trust and leader-member exchange. The Leadership Quarterly, 11(2), 227-250.

Burak, O.C., \& Bashshur, M.R. (2013). Followership, leadership and social influence. Leadership Quarterly, 24(6), 919-934.

Carsten, M.K., McGregor, R, Patera, J.L., West, B.J., \& Uhl-Bien, M. (2010). Exploring social constructions of followership: A qualitative study. The Leadership Quarterly, 21(3), 543-562.

Chaleff, I. (2009). The courageous follower: Standing up to and for our leaders (3rd ed.). San Francisco, CA: Berrett-Koehler Publishers, Inc. 
Collinson, D. (2006). Rethinking followership: A post-structuralist analysis of follower identities. The Leadership Quarterly, 17, 179-189.

Davies, B., \& Harre, R. (1990). Positioning: The discursive production of selves. Journal for the Theory of Social Behavior, 20(1), 43-63.

Deci, E.L., Connell, J.P., \& Ryan, R.M. (1989). Self-determination in a work organization. Journal of Applied Psychology, 74(4), 580-590.

Dervin, B., Foreman-Wernet, L., \& Lauterbach, E. (2003). Sense-making methodology reader: Selected writings of Brenda Dervin. Cresskill, NJ: Hampton Press.

Eisenberg, N. (1986). Altruistic emotion, cognition and behavior. Hillsdale, NJ: Erlbaum.

Gist, M.E. (1987). Self-efficacy: Implications for organizational behavior and human resource management. The Academy of Management Review, 12(3), 472-485.

Goffman, E. (1959). The Presentation of self in everyday life (1st ed.). New York, NY: Anchor Books, Doubleday.

Graen, G.B., \& Uhl-Bien, M. (1995). Relationship-based approach to leadership: Development of leadermember exchange (LMX) theory of leadership over 25 years: Applying a multi-level multidomain perspective. The Leadership Quarterly, 6(2), 219-247.

Hackman, J.R., \& Oldham, G.R. (1980). Work redesign. Reading, Mass.: Addison-Wesley.

Heath, R.L. (1994). Environmental risk communication: Cases and practices along the Texas Gulf coast. In B.R. Burelson (Ed.), Communication yearbook 18 (pp. 225-277). Newbury, Park, CA: Sage.

Howell, J., \& Mendez, M. (2008). Three perspectives on followership. In R. Riggio, I. Chaleff, \& J. Lipman-Blument (Eds.), The Art of followership: How great followers create great leaders and organizations (pp. 25-39). San Francisco, CA: Jossey-Bass.

Junker, N.M., \& van Dick, R. (2014). Implicit theories in organizational settings: A systematic review and research agenda of implicit leadership and followership theories. The Leadership Quarterly, 25(6), 1154-1173.

Katz, D., \& Kahn, R.L. (1966). The social psychology of organizations. New York, NY: Wiley.

Kellerman, B. (2008). Followership: How followers are creating change and changing leaders. Boston, MA: Harvard Business Press.

Kelley, R.E. (1988). In praise of followers. Harvard Business Review, 66(6), 141-148.

Korobov, N. (2010). A discursive psychological approach to positioning. Qualitative Research in Psychology, 7(3), 263-277.

Kuhn, E.S., \& Laird, R.D. (2011). Individual differences in early adolescents' beliefs in the legitimacy of parental authority. Developmental Psychology, 47(5), 1353-1365.

Lepisto, D.A., Crosina, E., \& Pratt, M.G. (2015). Identity work within and beyond the professions: Toward a theoretical integration and extension. In A. Desilva \& M. Aparicio (Eds.), International handbook of professional identities (pp. 11-37). Rosemead, CA: Scientific \& Academic Publishing.

Leroy, H., Anseel, F., Gardner, W.L., \& Sels, L. (2015). Authentic leadership, authentic followership, basic need satisfaction, and work role performance: A Cross-level study. Journal of Management, 4(6), 1677-1697.

Maitlis, A., \& Christianson, M. (2014). Sense-making in organizations: Taking stock and moving forward. The Academy of Management Annals, 8(1), 57-125.

Maslyn, J.M., \& Uhl-Bien, M. (2001). Leader-member exchange and its dimensions: Effects of self-effort and other's effort on relationship quality. Journal of Applied Psychology, 86(4), 697-708.

Parker, S.K, Wall, T.D., \& Jackson, P.R. (1997). "That's not my job": Developing flexible employee work orientations. Academy of Management Journal, 40(4), 899-929.

Rasmussen, A. (2012). Followership as an identity enactment. (Master's thesis, Copenhagen Business School, Copenhagen, Denmark). Retrieved from https://researchapi.cbs.dk/ws/portalfiles/portal/58420140/anders_rasmussen.pdf

Selznick, P. (1957). Leadership in Administration: A Sociological Interpretation. New York, NY: Harper \& Row.

142 Journal of Organizational Psychology Vol. 21(3) 2021 
Shamir, B. (2007). From passive recipients to active co-producers - Followers' roles in the leadership process. In B. Shamir, R. Pillai, M. C. Bligh, \& M. Uhl-Bien (Eds.), Follower-centered perspective on leadership: A tribute to the memory of James R. Meindl. Greenwich, CT: Information Age Publishing, Inc.

Spreitzer, G. (2007). Taking stock: A review of more than twenty years of research on empowerment at work. In J. Barling \& C.L. Cooper (Eds.), The SAGE handbook of organizational behavior: Volume One (pp. 54-72). Thousands Oaks, CA: SAGE Publications, Inc.

Spreitzer, G.M., Kizilos, M.A., \& Nason, S.W. (1997). A dimensional analysis of the relationship between psychological empowerment and effectiveness, satisfaction, and strain. Journal of Management, 23(5), 679-704.

Starbuck, W.H., \& Milliken, F.J. (1988), Challenger: Fine-tuning the odds until something breaks. Journal of Management Studies, 25, 319-340.

Sy, T. (2010). What do you think of followers? Examining the content, structure, and consequences of implicit followership theories. Organizational Behavior and Human Decision Processes, 113(2), 73-84.

Uhl-Bien, M., Riggio, R.E., Lowe, K.B., \& Carsten, M.K. (2014). Followership theory: A review and research agenda. The Leadership Quarterly, 25(1), 83-104.

Waterman, A.S. (1990). Personal expressiveness as a defining dimension of psychosocial identity. In C. Vandenplas-Holper \& B.P. Campos (Eds.), Psychological development. Interpersonal and identity development: New directions (pp. 103-112). Instituto de Consulta Psicológica, Formação e Desenvolvimento.

Weick, K.E. (1995). Sense-making in organizations: Foundations for organizational Science $\left(1^{\text {st }}\right.$ ed.). Thousand Oaks, CA: SAGE Publications, Inc.

Weick, K.E., Sutcliffe, K.M., \& Obstfeld, D. (2005). Organizing and the process of sense-making. Organization Science, 16(4), 409-421.

Youssef, C.M., \& Luthans, F. (2007). Positive organizational behavior in the workplace: The impact of hope, optimism, and resilience. Journal of Management, 33(5), 774-800. 